\title{
Reflections: Students' Tribute to Stan Kuczaj (1950-2016)
}

On April 14 ${ }^{\text {th }}$, 2016, Animal Behavior and Cognition lost its Editor-in-Chief. But the scientific community and the friends and colleagues of Stanley 'Stan' Kuczaj III lost so much more. As many know, Stan began his career in Developmental Psychology, making enormous contributions in the area of language development, but became best known for his many innovative contributions in the area of marine mammal behavior. Stan founded Animal Behavior and Cognition because he was deeply passionate about research with a broad range of topics concerning animal behavior, animal cognition, and animal welfare. He was equally passionate about the idea that science should be accessible to all, and that accessibility should not come at a financial burden to researchers. The current editorial team is committed to carrying on Stan's vision for the journal, and we believe that its continuation will pay homage to Stan as a researcher, and as a leader within the scientific community.

However, for the next few pages, we wish to pay special tribute to Stan as a mentor, as this role was perhaps the one that was most pivotal in defining who he was as a scientist, colleague, and friend. We take comfort in the fact that Stan's memory will live on in the legacy of his mentees, many of whom became cherished friends and colleagues. Below you will find reflections from several of these former students who were given the difficult task of trying to summarize the most meaningful aspect of Stan's influence on their personal and professional development. Although no few words could summarize the impact of someone as enigmatic as Stan, we hope that these reflections will contribute to a full and nuanced tribute to the man he was.

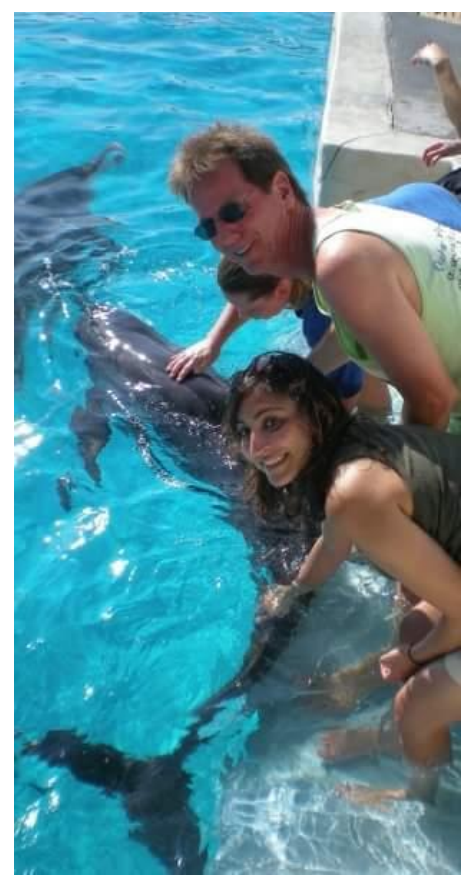


Stan was the master of collegial collaboration. He worked successfully with so many people across so many fields because he could work with anyone, building meaningful partnerships that drew on each contributor's strengths. Whenever I am trying to do the same, and become frustrated with people, situations, or bureaucracy, it will forever be Stan's voice I hear in my head, urging patience and staying open to other possibilities, and laughing at the absurdity of it all.

-Mark Zitco Jr. (1990-1996)

Life has a funny way of getting us to where we ultimately want to be, whether we know it yet or not. Dr. Stan Kuczaj represented the other side of my unexpected curve in life that was my graduate education and ultimately, my future career. A kind, wickedly funny, and avid sports fan, Stan showed me how to combine my interests in development, language, cognition, and marine mammals into a life-long pursuit and passion. Nothing was impossible. What began with an interest in understanding dolphin communication developed into a much broader perspective of how marine mammals can teach us a little something about both their world and ours. His ability to tease constructively taught me to laugh at my-less-than-perfect self while also learning to believe in my abilities. It was tough to keep up our weekly three-hour "therapy" sessions where we talked about life, dolphins, and future goals, but Stan always made sure to check in and make sure life was good. He was my mentor, friend, and collaborator, and he taught me that the most important part of teaching and mentoring was to listen and guide while asking tough questions. Stan was truly "the Man," inspiring me to pursue the roads less traveled. I can't thank him enough for encouraging me to pursue this "crazy dolphin dream"!

-Heather M. Hill (1997-2003)

The Butterfly Effect - small initial differences may lead to large unforeseen consequences over time (Wikipedia).

Some experiences I had while completing my undergraduate honors project on chipping sparrow acoustics were so averse that I had no desire to further my education. However, Stan bestowed on me a gift that cannot be bought... a safe and trusting environment in which one could expand their academic horizons. Based upon a greeting card signed "Stan" that I received I decided to try trust again. That card suggested that Stan might be conscientious and understanding. Stan was all of that and more, not only during my formal education, but also for the following ten years.

In 2010, I was experiencing some personal challenges and still was not engaged in the research I have been driven to do since I was seven years old. Stan caringly reached out to me and as an after-thought, invited me to contribute to a manuscript on cetacean play behavior. In tracking down an original reference for that paper I connected with some wonderful people. And that is why I am composing these thoughts from a remote section of the Peruvian Amazon that can only be accessed by airplane or boat. Thanks to Stan, I am here studying the bioacoustics of the two species of Amazon River dolphins, Inia geoffrensis and Sotalia fluviatilis. In addition, colleagues from the U.S., Peru, Chile and France will be meeting me here in the jungle in July to further develop high-frequency recording equipment, model acoustic propagation, and lay the foundations to a permanent bioacoustics research station in the Amazon. 
A friendly signature and a casual invitation have rippled out to largely impact my life and those of so many others! I am just one of many whose lives have been touched by Stan's Butterfly Effect. I thank Stan from the bottom of my heart and the far reaches of my soul. I strive to emulate Stan's encouraging and empowering, yet humble, disposition daily.

The world has become a bit darker, while heaven much brighter...I hope that Stan is swimming and playing with all of the flippered friends we have known. Thank you for all of your guidance, support, friendship, and laughter, I could not have accomplished what I have already done, nor what awaits in the future without you. As long as I live, you will continue to live and be expressed in my thoughts and actions. Thank you for believing in me. Sharing Thai food at the Comparative Cognition Conference 2016 would have been so excellent...I (like many others) was not ready to see you leave...

-Marie Trone (1999-2006)

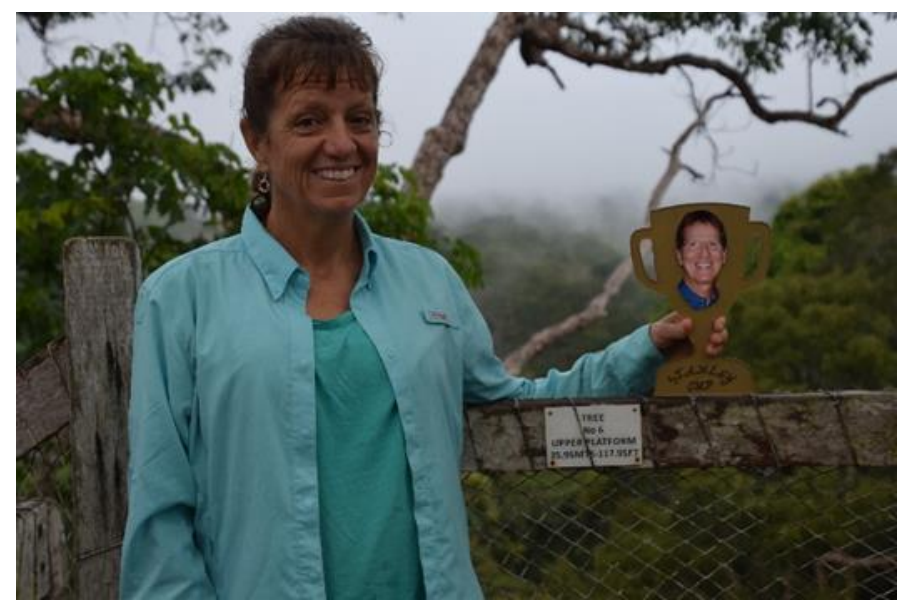

Stan always consistently guided and directed me to the knowledge and experiences that I needed to develop in our discipline. He took a risk taking me on as a graduate student due to my lack of knowledge in psychology. He facilitated my understanding of the connection between biology and psychology in the field of animal behavior. As a marine biology undergraduate student he gave me the opportunity to collect observational data of bottlenose dolphins.... as long as I took his Principles of Learning class. At that time I had never even taken General Psychology. It was my first experience really learning about what psychologists studied. While I found it very interesting I still was not ready to make the jump from biology to psychology. Stan gave me the opportunity to continue as a master's level student in marine biology but conduct my research under his guidance. During that time he exposed me to research in the field of behavior and cognition in marine mammals. I finally made the move to psychology for my Ph.D. Throughout that time I appreciated how he provided me with learning and critical thinking experiences in research. He also realized that teaching was an area that I would thoroughly enjoy. Over the years he continued to provide guidance and support. He inspired me to continue teaching and spread the importance of comparative psychology. He was a wonderful mentor, colleague and friend. He motivated me to allow students unique opportunities and see where they go with it!

-Rachel T. Walker (1999-2005) 
While I did not know him for very long he made a long lasting impact on my life. I remember him as a person who smiled a lot and was always there if you had a question or a problem. He created an atmosphere of cooperation and fellowship in his graduate students that has lasted through the years. He expanded our view of the world while teaching us how to ask intriguing scientific questions. During my last year of grad school I was diagnosed with cancer. I will always appreciate how he supported me and I cannot express the impact this made on my life at the time. He made it so that I could finish my research and defend my thesis around my cancer treatment schedule. I will never forget him.

-Kymbr Wright (1999-2001)

Stan Kuczaj played a huge role in both my personal and professional development. Without him, I would not have the career I have today. He taught me to be professional, taught me how to write well, and taught me how to be a thorough researcher. He introduced me to everyone that I know and collaborate with now and without his support, I would not have the job I have today. Personally, Stan was like a second father to me. He taught me about love, compassion, friendship, kindness, and that family is not always related by blood. He was always there for me, even years later, whether he was calling to check on me when my father was in the hospital or whether he was sending a yearly birthday card. I loved Stan more than words could express, and I was so lucky to have him as my graduate mentor, colleague, and friend. Apart from my parents, Stan made me who I am today. I hope everyone is as lucky I was to find a mentor like him.

-Radhika Macheka (2002-2008)

Supervision with a Smile

I met Stan Kuczaj in Gran Canaria at a conference of the European Cetacean Society. At the time, I was a lowly Masters student seeking a thesis project. He invited me to come out and work on some of his data. Such a willingness to share data is not as common as it perhaps should be in our field. Yet Stan was always open to and accepting of new people and new collaborations. Thus Stan became my external supervisor.

When I arrived in Hattiesburg, Mississippi, Stan and his lab were incredibly welcoming and all helped my wife and I find a place to live and generally settle in. As I ploughed through the mounds of acoustic data, Stan gave me the freedom to develop my own approach, but was always there if I needed some advice. He also introduced me to others with more technical expertise in acoustics that could help further, freely sharing his connections and contacts. Stan guided me through the steep learning curve that was my MSc thesis with a constant cheerful air that made it all seem possible, even when the task seemed insurmountable. He was also kind enough to find small pockets of money to give me - his external student - occasional work that allowed me to worry just a little less about grocery shopping, and the like.

After the MSc I moved away from Hattiesburg, but Stan and I continued to collaborate on various projects. On my visits and when we connected at conferences, Stan was always very keen to involve me in Lab-related events. It was like I had never left. He always had a big smile when we met. Always time to catch up. So this will be my enduring memory of Stan: welcoming, inclusive, collaborative, generous, and always with a smile.

-Andrew J. Wright (2003) 
Stan was a great mentor. He really fostered independence in his graduate students, while still always being there for support. He encouraged me and all of his other students to work on thesis / dissertation ideas that we developed as students rather than assigning us a project based on whatever grants he had at the time. He was always there to guide us along the way, but he gave me the space and freedom to develop as a researcher.

He was also a role model of how to be a great teacher in the classroom while maintaining a grant funded research program with a cadre of graduate students! I really enjoyed being in his classes, and he gave great advice about becoming a future faculty member. I remember once I was frustrated with the workload as a graduate research assistant who was also taking several challenging graduate courses. He listened kindly, then explained the additional expectations of a faculty member at a research intensive institution. Now that I am a faculty member myself, I admire the way that he handled my moment of "venting" as a teachable moment about the career to come. He was sympathetic but also wanted to give me a dose of reality about the future.

In addition to being a caring and effective mentor, Stan loved to have fun. I'm sure you will hear many stories about how he enjoyed dancing and socializing with colleagues. He had an infectious, mischievous smile and knew how to make people feel at ease. He will be missed.

-Erica Hernandez (2003-2007)

As my mentor, close friend, and research collaborator there is really no aspect of my life that has not been greatly impacted by Stan's influence. Stan has helped to shape me into the person who I am today. I am constantly reminded about things he has taught me about academics, research, and life in general. He was my serious mentor, but also became my fun, goofy, and caring friend. I am forever grateful that I was lucky enough to have 13 great years of working with him.

-Deirdre Yeater (2003-2008)

I remember our very first phone call and hearing that raspy voice of his for the first time. He was so kind and welcoming, and I knew immediately I wanted to be his graduate student. Stan was one-of-a-kind. He was well liked by everyone he met and researchers from around the world wanted to collaborate with him. His career and dedication to research will continue to inspire others. There were so many wonderful things I cherished about him. If I had to pick one it would be his friendship and support. In between taping documentaries or being interviewed by National Geographic, he still had time for me (even long after I had graduated from his program). He often called just to say hello. I could always count on him for guidance and that is one of the things I will miss the most. He was one of the greatest influences in my life, and I am eternally grateful that I was afforded the opportunity to know him.

-Lauren Highfill (2004-2008) 
On April 14th 2016 I lost a mentor, a colleague, but most importantly a friend. I will always miss the times catching up and reflecting on sports and music. Talking about everything from the Grateful Dead to the Texas Rangers and Dallas Cowboys. However, what I will miss the most about Stan was his amazing passion for research and his quest for knowledge. He was never one to turn down a new research project even if outside of his normal areas of interest and would always inquire about what we could work on together next. I learned a lot from him over the years, both as his student and his colleague, he is truly missed.

\section{-Lance Miller (2005-2009)}

\section{Dear Stan,}

It has been a couple of months since you left us, but this is the letter I wish I had given you earlier.

Everyone in life needs a mentor, someone to help guide him or her along the way, especially in this world of marine mammal research. For some reason I was given the most incredible gift...to be mentored by you. From the first time we met, you always treated me as your colleague, eager to cultivate ideas, expand existing projects, and, something that you'll never know how much I appreciated, listened when times were challenging. You were supportive of my research efforts and unbelievably generous with your time, making me feel significant. I was enamored by your ability to seamlessly build relationships with students and professionals in the field, with deeply rooted mutual admirations; you personified and embodied humbleness. Even in your absence, you will always be my mentor.

During the past decade, our professional relationship developed into an unexpected friendship that has been equally impactful in my life. I will continue to practice your mantras of perseverance, it's impossible to please everyone, and that great ideas can come from the most unexpected of places. You had a way of directing focus to always live in the moment, as well as teaching how to move past life's obstacles by not letting them consume you. You continually gave strength to me along the way, and cultivated a spirit of happiness and joy. Your boundless love and support gave me the courage to believe in myself, and I can truly say that I was one of the blessed to call you my friend.

While reflecting back I remember countless memories of fun, laughter, and craziness! You would constantly bring or send Conrad and I bizarre (I mean...unique) gifts that are now everywhere in our home and as we see them daily we are reminded of the greatest gift you ever gave us, the gift of YOUR time. The time to enjoy the real Stan Kuczaj, not just the world-renowned scholar, but the man that became one of our dearest friends. I knew our friendship was special when you started visiting us in Key Largo and the trips had nothing to do with research. Trips taken just to hang out with us; sit on the couch and wax philosophically about life, go out to a waterfront pub to listen to live music and have cocktails, or just stay home to watch a movie and cuddle with Reef. Which, by the way, you've brought Reef enough funky dog toys to last him a lifetime. Not to mention his extra weight from you feeding him peanut butter stuffed pretzels with your toes. It also cracked us up that you would never pass up the opportunity to reuse a joke, especially the one about being invisible while wearing camouflage pants. Um Stan, we could see you, sorry. Even your necessity to eat something every hour or so would turn into an adventure when a three-hour boat trip once became a pseudo rescue mission because we didn't feed you and you passed out on the bow. You shared the art of behavioral observations at Waffle House, as well as the energy of Blue Grass music festivals in Louisiana. However, the most memorable moments were the ones filled with 
belly laughs wrapped up in our Snuggie Christmas gifts. You found enjoyment and appreciation in the small things, and would constantly remind us that life was short.

Stan, you were my dear friend, a gifted scientist, and loved by all. I thank you for the caliber of man that were and you are a tribute to those people who go out of their way to help others pursue their dreams! Please rest easy my friend and know for certain, with all my heart, I will continue your mission, your work and love for life.

Much Love!

-Holli Eskelinen (2007-2010)

Sometimes we find what we are looking for in the most unexpected places, the last place you think you'd look. Such is my story in coming to Dr. Stan Kuczaj. I've spent most of my life chasing killer whales; dedicating my life to understanding and conserving their existence, their cultures rooted in learned dialects and family traditions resonating for generations within worlds of mountains and mist were everything I had ever wanted. So imagine my surprise when my path to a life studying killer whales led me thousands of miles away...to Mississippi. The irony here, is that I grew up in Mississippi; the very ground that held my own matrilineal roots which so paralleled the animals I sought to understand would be the key to a future I'd always hoped for.

Most advisors, when seeking students, don't often allow the flexibility to create or pursue 'dream projects' and instead have them focus on existing or already funded research initiatives. Not so with Stan. He was extremely supportive and receptive of hosting my own project which I had crafted over several years. I will never forget the day he called me to tell me personally that I was admitted to his program; I was over the moon to be given the chance to become Dr. Smith.

My years in Mississippi working with Stan were pivotal to my career. He welcomed any idea I put forward and gave me plenty of rope to run with, but never enough to really trip over. Start a Society for Marine Mammalogy student chapter? Go for it! Organize a symposium? I'll see you there! No matter how many grant proposals and letters of recommendation requests I sent his way - and there were MANY, he was always there to collaborate and support me and to keep me moving forward.

Our student-advisor relationship wasn't always what we had hoped from each other, but our challenges ultimately forged a solid professional partnership and camaraderie -- and in the end I am proud to say we were friends. His advising shaped me into the professional that I am now, and for that I will always be thankful for him. Although he is gone, I take comfort with our extended lab family, many of whom have become my life-long collaborators and friends. Stan's legacy was his students and his impact on the many lives he touched will go on in perpetuity. Descansa en paz...

-Courtney Smith $(2009 \ldots)$ 
Unfortunately for me I entered Stan's lab just after Alabama defeated Texas in the national championship. He just could not let it go that I am an Alabama fan. He really enjoyed that he had something he could tease me about. That was one of the great things about Stan. He found something in all his students that he could talk and laugh with us about outside of school and research. He found what was unique about each of us and developed a different relationship with all of his students. I think this ability to look past superficial characteristics and to pay attention to the specifics is what gave him such a critical eye reviewing research. This was something he worked hard to instill in all his students and one of the things I appreciated most about him as a mentor.

-Pepper Hanna (2010-2016)

From the first time I met Stan, and he was wearing his standard outfit of croc flip-flops, cargo shorts, and a t-shirt, I already knew I had picked the right advisor! And every time I would talk to him or send him an e-mail about something I was really excited about and I got a genuinely enthused "Yay!!" in response it would make me smile and giggle. Stan's passion for knowledge and life was infectious! He was always ready and willing to move our lab meetings to Keg on days with nice weather and his face always lit up when you brought snacks to lab meeting or his office, but he was equally excited when you came to him with an idea about a new research opportunity or when you finally had that light bulb moment that he had been "gently nudging" you toward. Stan was an amazing lecturer and always had such passion in his eyes when teaching us, but there was something truly magical about getting to see him in his element outside of the classroom. I was fortunate enough to get to see him on boat trips in The Mississippi Sound, The Bahamas, and even seeing him collecting data with the dolphins in Roatan, Honduras. It was in these environments that his normal sense of humor and his quest for knowledge became even more vibrant and it was truly inspirational to watch the passion with which he worked. I will always be thankful to Stan for believing in me, for all of those little nudges, for emulating that you could create your own unique path and stay true to yourself, that you can both be professional and have a sense of humor, to always think critically, and most importantly, to always do what you love.

-Beri Brown (2010-2016)

As a mentor, Stan was entertaining and encouraging. I immensely enjoyed the long talks we would have that would begin with fleshing out a project idea and end on discussing Texas cuisine. He was funny and charismatic, which always made meetings highly enjoyable. His critical way of assessing information taught me a great deal about the importance of skepticism in science.

-Kelly Winship (2012-2016)

After almost 5 years as his student I can say that I have met few people as generous and supportive as Stan. I came to lab with some data from a previous project I led in Colombia. Stan was very supportive of me continuing data collection related to this project and here I am collecting my dissertation data. I will always treasure the memories I have of him, of his sense of humor and the private jokes he had with each of us. He is, and will be, greatly missed.

-Natalia Botero $(2011 \ldots)$ 
I can definitely say that I would not be where I am today without the influence of Stan on the work that I do. I am forever grateful for everything he has done for me, as an advisor and mentor, but I am most grateful for how he helped me realize my full potential as a researcher. The amount of responsibility he placed on me, as well as trusting me to accomplish so many tasks and help take care of business has helped make me the confident self-empowered researcher and person that I am today. He also introduced me to Roatan, a place and facility that has become a focal point in my research career and showed me how fun and full of life Stan could be. I am forever grateful to have known and worked with you. We miss you Stan, and hope that you know how much we all loved you.

\section{-Erin Frick $(2012 \ldots)$}

I am infinitely grateful to Stan for giving me the opportunity to turn my childhood daydreams into a fullfledged career. Stan generously shared his experiences and resources in order to help his students become independent, thoughtful researchers. The lessons he taught me will continue to impact my work throughout my career. From all whose lives and careers you influenced, thank you.

-Lisa Lauderdale $(2012 \ldots)$

Of the many things Stan taught me, the most important was to always chase the complicated questions that fascinate, inspire, and drive us; and the best way to do that is to answer each little piece at a time. We were always encouraged to shape our studies around shedding light on some aspect of cognition or behavior, while scrutinizing the details to ensure a sound design. To better our research, he showed us the importance of staying open to incorporating new ideas, bridging different disciplines together, and including the insights found in the most unlikely places. Daily, Stan demonstrated that the best work comes out of a love and fascination with both your topic and subjects. I will be forever grateful that he supported and empowered me to do so, too.

-Kelsey Moreno (2013...)

No matter what when I was around Stan, I could expect either a good laugh from his quirky sense of humor or a new challenge that grew me as a student and a scientist. Although we all joke about it, I secretly loved when he would stand in the lab, coffee cup in hand, beaming with pride at his devoted "pod of porpoises" working diligently in hopes of one day being qualified enough to have our names printed in ink alongside his. All I can say is thank you Stan for everything you have taught me and the opportunities you have provided me over the past three years. You are and will always be missed very much. I can only hope that I will make you proud throughout the rest of my career.

-Kendal Smith (2013...) 
Stan was my mentor, but he was also my friend. He taught me how to crawl when I was an infant, and from there I ran to work with him. I admired him so much when I was growing up, and becoming his graduate student was to be the pinnacle of my early career. Stan's natural habitats were the field and the classroom. There he shined, and it was so apparent his love for his students and his love for the animals. I will forever be indebted to Stan for all that I learned during my time as his student. I am so proud to carry on his legacy because Stan meant the world to me. He has shaped my entire life, and will be greatly missed.

-Audra Ames (2013...)

I am truly honored that I came to know Dr. Stan Kuczaj. Not only did he share his expansive knowledge with me but guided me on the path to becoming the researcher I am today. As a mentor, he believed in me and pushed me to always do better and as a friend, we shared many laughs. From adventures in Roatan, to jokes in lab, to eating at the 1920s diner Coney Island, I'll always remember these with a smile. Thank you for everything Stan, you are dearly missed.

-Ali Taylor $(2014 \ldots)$

Stan has influenced my research by demonstrating with his actions and words the importance of acknowledging individual differences in study subjects' behavior and cognitive abilities. Stan taught me that each species has unique skills and abilities that make them intelligent in their own right. This has inspired me to seek answers to the question that Stan has always asked, "How are dolphins intelligent?" I hope that his humble approach to science will continue to influence me throughout my career.

-Malin Lilley $(2015 \ldots)$

I met Stan in Roatan, Honduras the summer of 2015. Little did I know that on this trip abroad I would not only gain a new mentor but also a friend. As a biology student transitioning into the field of Psychology, Stan was always supportive and seemed to have more faith in me than I had in myself. Stan viewed my failures and shortcomings, as learning experience and potential, rejoicing in my success no matter how small. Stan has helped me to grow professionally, challenged me to think critically, and has shown me what it means to love what you do. Stan has forever changed the way I view and approach animal behavior as a whole. Every day I see him in my work and as I progress with my degree I feel his continued guidance in everything I do.

-Briana Cappiello (2015...)

Although I did not know Stan as long as other students, I learned a lot in my short time with him. Stan always encouraged us to pursue our own specific research interests, and helped us any way he could. He was very accepting of all of his students, and pushed us to do our absolute best. He was an exceptional researcher, caring mentor, and all around great man. I hope to carry on his legacy and make him proud as I begin my first year of graduate school this Fall.

-Riley Macgregor (2015...) 
It is our hope that these reflections will continue to inspire others to be the very best students, scholars, and mentors that they can be through the influence of a man they may not have had the fortune of knowing. We feel incredibly lucky to have been inspired by Stan Kuczaj. He will be sorely missed.

Jennifer Vonk, Michael Beran, and Heather Hill

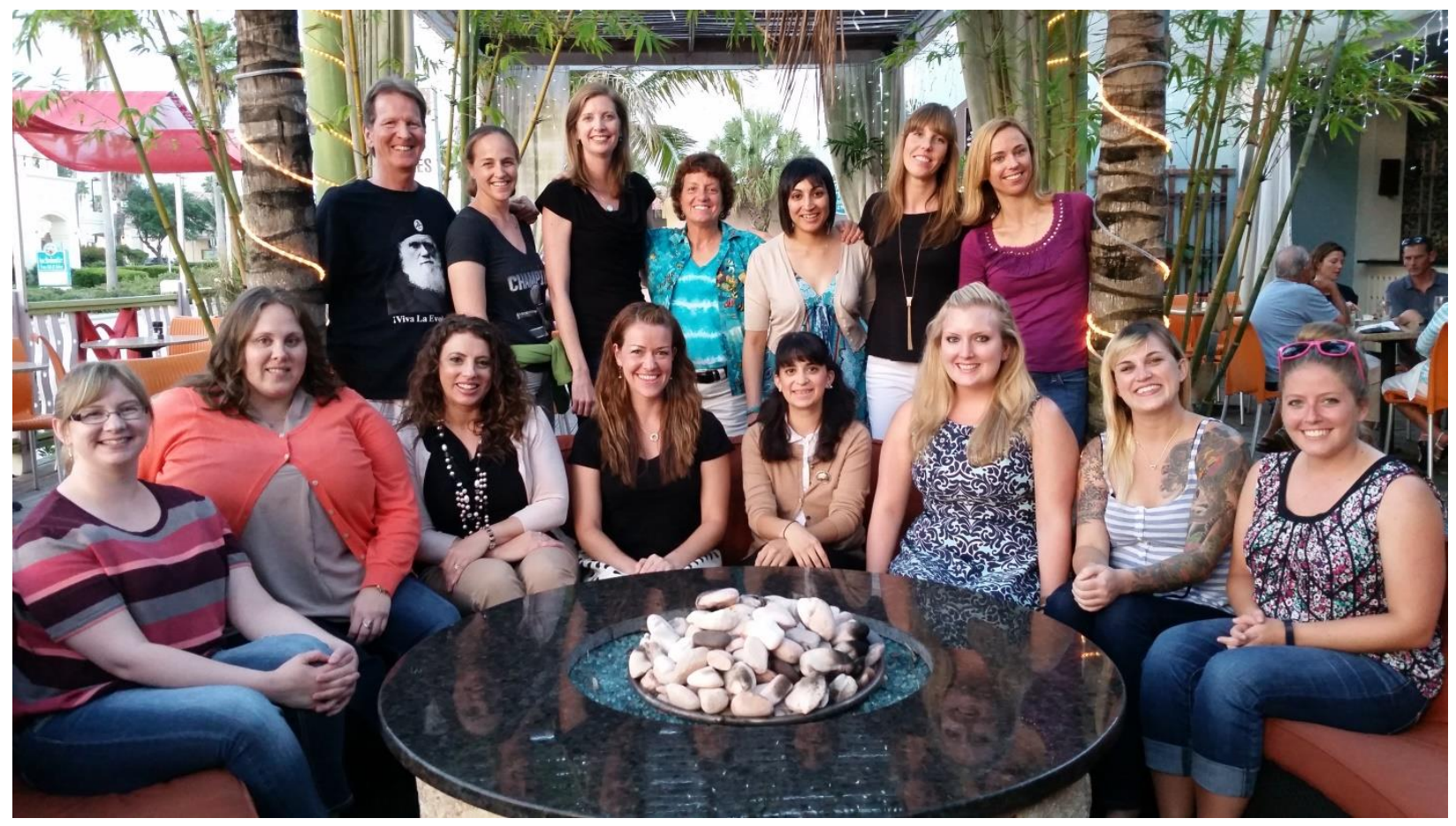

